\section{ASSESSMENT OF SUBCLINICAL MASTITIS EFFECTS ON LIVE WEIGHT, BODY CONDITION SCORE (BCS) AND EXTERNAL UDDER MEASUREMENTS OF DORPER SHEEP}

\author{
Amirah Wan-Azemin, Asmad Kari*, Nadiawati Alias
}

Faculty and Bioresources and Food Industry, Besut Campus, Universiti Sultan Zainal Abidin, 22200 Besut, Terengganu, Malaysia
Article history

Received

20 September 2020

Received in revised form

17 December 2020

Accepted

5 January 2021

Published online

23 February 2021

*Corresponding author asmad@unisza.edu.my

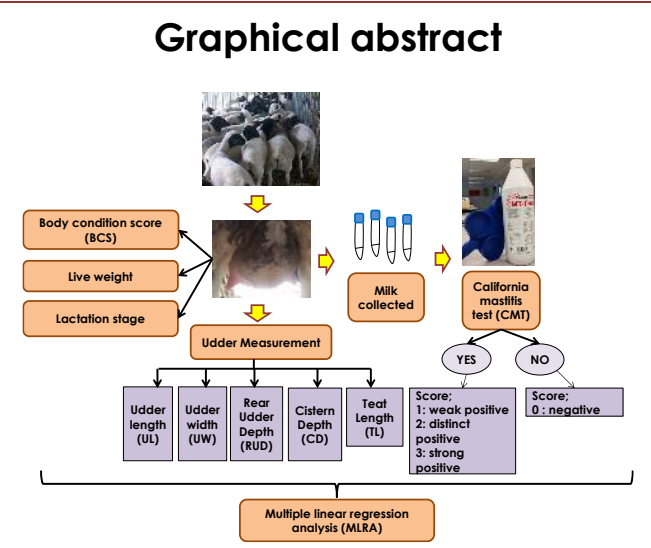

\begin{abstract}
Mastitis is an inflammation of the mammary gland that can be classified as clinical and subclinical mastitis. The clinical mastitis can be diagnosed based on clinical signs, whilst subclinical mastitis mostly through somatic cell count (SCC). This study was carried out to determine the subclinical mastitis effects on live weight, body condition score (BCS) and external udder traits of Dorper sheep. A total 16 Dorper ewes were selected and screened for mastitis using the Californian mastitis test (CMT). The live weight, BCS and external udder traits (i.e. udder length (UL), udder width (UW), rear udder depth (RUD), cistern depth (CD) and teat length (TL) of the ewes were measured. The subclinical mastitis did not affect the live weight and BCS of Dorper ewes. Whilst for external udder measurements; the highest average of udder length, udder width, rear udder depth and cistern depth were indicated in CMT score as strong positive which shows that the measurement values of external ewes' udder are increased when the strength detection of CMT scores increased and vice versa. However, all of the external udder parameters measured were not statistically $(P>0.05)$ affected by the mastitis infection scores. The present results indicate that live weight, BCS and all external udder parameters did not influence the subclinical mastitis detected in the milk's samples of the ewes. This study suggests that subclinical mastitis does not directly affected by morphology alteration of external udder traits, live weight or BCS, however it is likely affect the quality of milk produced.
\end{abstract}

Keywords: Live weight, body condition score (BCS), external udder traits, mastitis infection scores (CMT), subclinical mastitis

\begin{abstract}
Abstrak
Mastitis adalah keradangan gelenjar susu yang boleh dikelaskan sebagai mastitis klinikal dan subklinikal. Mastitis klinikal dapat didiagnosis berdasarkan tanda-tanda klinikal, sementara mastitis subklinikal kebanyakannya melalui jumlah sel somatik (SCC). Kajian ini dilakukan untuk mengetahui kesan mastitis subklinikal terhadap berat badan hidup, skor keadaan badan (BCS) dan ciri-ciri tetek biri-biri Dorper. Sejumlah 16 biri-biri Dorper betina dipilih dan disaring untuk mastitis menggunakan ujian mastitis california (CMT). Berat badan hidup, skor keadaan badan dan sifat luaran tetek (i.e. panjang tetek (UL), lebar tetek (UW), kedalaman tetek belakang (RUD), kedalaman tangki (CD) dan panjang puting (TL)) biri-biri betina diukur. Mastitis subklinikal tidak mempengaruhi berat hidup dan BCS biri-biri betina Dorper. Mastitis subklinikal tidak mempengaruhi berat hidup dan bcs biri-biri dorper. Sementara untuk ukuran luaran tetek; purata tertinggi daripada panjang tetek, lebar tetek, kedalaman tetek belakang dan kedalaman tangka ditunjukkan pada skor CMT sebagai sangat positif yang
\end{abstract}


menunjukkan bahawa nilai pengukuran luaran tetek biri-biri betina meningkat apabila pengesanan kekuatan skor $\mathrm{cmt}$ meningkat dan sebaliknya. Walau bagaimanapun, dan semua parameter luaran tetek tidak dipengaruhi secara statistik ( $P>0.05$ ) oleh skor jangkitan mastitis. Hasil ini menunjukkan bahawa berat hidup, BCS dan semua parameter luaran tetek tidak mempengaruhi mastitis subklinikal yang dikesan dalam sampel susu biri-biri betina. Kajian ini mencadangkan bahawa mastitis subklinikal tidak terjejas secara langsung oleh perubahan morfologi sifat luaran tetek, berat badan hidup atau BCS, namun kemungkinan ia mempengaruhi kualiti susu yang dihasilkan.

Kata kunci: berat hidup, skor keadaan badan (BCS), sifat luaran tetek, skor jangkitan mastitis (CMT), mastitis subklinikal

(C) 2021 Penerbit UTM Press. All rights reserved

\subsection{INTRODUCTION}

Sheep dairy products are one of the important contributions towards great economies in many parts of the countries. Any major disturbance in optimal producing of both quantity and quality of milk in sheep may leads to greater financial losses such as in cheese production that using milk as main ingredient [1]. Present of diseases such as mastitis is an important economic and health issue in sheep [2]. Clinical mastitis has potential for ewes' death due to the painful udder infections, lamb deaths from starvation and consequently the permanent udder damage that leading in culling and decrease ewe production [2, 3]. Besides, subclinical mastitis more accompanied by numerous changes in milk composition that contribute to reduce milk production and milk quality due to udder damage including lower lactose and calcium content, the concentration of whey proteins, sodium and chlorine are increase, an alteration in the proportion of casein and reduce in lipid concentration [1]. Also this may result in poor growth rates or deaths in lambs due to starvations or bacterial infection from consuming infected milk and later subclinical mastitis may lead to clinical mastitis $[2,4]$.

In EU dairy sheep, around 60 million per annum could be losses from the total milk production for $10 \%$ incidence of mastitis [5]. Mastitis is an inflammation of the mammary gland which is a common in ewes and is known as a sporadic disease in ewes. Mastitis is complex health problem in small ruminant due to involve multiple factor sources including different pathogenic agents such bacteria, fungus or viruses, variable severity of ewes itself and farmers management [6] and it still remains as the most costly and major diseases in the veterinary field especially in the dairy industry worldwide [5,7-9]. Mastitis is major disease in dairy field due to its cause severe economic losses and large impact on ruminant which affect the milk production (quality and quantity), animal health [5, 7, 10, 11] and human public health impact due to the severe human infections attributed to the consumption of dairy products that mastitis pathogens resistant to antimicrobial agents that not destroyed in raw milk or milk during thermal processing, thus pathogens also could be transferred to humans and become main source of enterotoxigenic that produce heat resistant as well as causing food poisoning outbreaks [12-14].

Commonly, mastitis can be detected by the inflammation of the mammary gland due to the infection of pathogens [5, 11]. Mammary gland infections can be classified as clinical or subclinical mastitis in sheep. Clinical mastitis often present as severe condition of mammary gland which lead to complete damage and obviously painful such as swelling, redness or necrosis in the udder, or severe systemic signs such as high temperature (fever 105107F), anorexia or agalactia, go off feed, become depressed and even lead to death $[5,15,16]$. However, subclinical mastitis cannot be diagnosed by routine mammary gland examination but it can be identified by changes in milk composition using indirect method as preliminary test by measuring inflammatory indicators in milk such as California Mastitis Test (CMT), somatic cells count (SCC) and changes in milk constituent [10, 17-19]. The preliminary detection of subclinical mastitis in sheep is major concern due to its can prevent more or severe infection among livestock farms. In addition, subclinical mastitis also cause significant losses where it presents a higher occurrence that linked to negative consequences on milk production, impaired milk quality, demand veterinary expenses or drugs, shortened productive life of animal and increased the cost of replacement $[20,21]$.

The California Mastitis Test (CMT) is a conventional diagnostic technique that commonly used for healthy udder examination and has been accepted use due to cheaper price, faster measurement, simple protocol and effective diagnostic tool [7, 9, $21,22]$. This method is very useful which only required small amount of milk to react with CMT reagent which contains a detergent that reacts with DNA of cell nuclei and a $\mathrm{pH}$ indicator in milk and the reaction level is scored proportional to the concentration of somatic cells present [5, 18]. In addition, the intra-mammary infections in sheep may also affect due the teats placement and udder 
conformation where the small udder, horizontally teats and inappropriate udder confirmation (deep and pendulous udder) may increase exposure to injury and contamination and then related to greater risk of mastitis disease [23]. Previously, [24] co-worker also confirmed that the pendulous udder was significantly associated with mastitis, whereas subclinical mastitis is invisible and relies on somatic cell count (SCC) or California Mastitis Test (CMT) as an indicator [25-27]. Thus, this situation has raised the concern among farmers or dairy producers since undiagnosed subclinical mastitis can probably be an possible source of infection for other lactating animals.

The mastitis infection can be caused by many factors such as poor live body weight and body condition score, environment and the hygienic aspects of the animals. The ewes with poor body condition are potentially to have low milk production that may cause the hungry lambs to bite the teat harder and subsequently lead to udder damage or teat lesions that can lead to severe mammary gland infection or clinical mastitis [28].

Thus, the aims of this study were to examine the subclinical mastitis effects on live weight, body condition score (BCS) and external udder traits of Dorper sheep and to determine the relationships between udder parameters and CMT score. In addition, the parameters of udder measurements especially their relationship with right and left side are presented and discussed as for now there was no study conducted in dairy sheep in Malaysia. The identification of the relationship between subclinical mastitis with live weight, body condition score (BCS) and external udder measurements in Dorper sheep breed was a useful knowledgement for a major advancement and contribution to the small ruminant field.

\subsection{METHODOLOGY}

\section{Animal and Clinical Data}

A total of 16 Dorper ewes ( 6 years old of age) were selected and screened for mastitis using the California Mastitis Test (CMT) in three groups of lactation stages (group 1: 0 -15 days; group 2: 16 -30 days; and group 3: 31 -45 days) with apparently healthy udders and maintained at the farm ECER/FELDA Agropolitan Besut-Setiu, Terengganu were used in the present study. The farm was coordinated longitude and latitude at $5.4534^{\circ} \mathrm{N}$ and $102.8846^{\circ} \mathrm{E}$, respectively. The ewes were placed in animal house and regularly fed with concentrates and forages (Napier grass) which is cut and carry as well as water adlibitum. Also, the management of the animal always applied the treatment of mastitis on ewes. The live weight (measured by using farm measuring scale), body condition score and external udder traits (i,e. udder length (UL), udder width (UW), rear udder depth (RUD), cistern depth (CD) and teat length (TL) of the ewes were then measured.

\section{Measurement of Body Condition Score (BCS)}

The assessment of body condition score (BCS) of ewes was easy and quick procedures described by [30] in order to determine the healthy condition of ewes. A hand was placed over around the backbone and loin area behind the last rib to feel the amount of fat cover and muscle mass of ewes showed in Figure 1. The scoring scale was used from 1 (very thin) to 5 (very fat) and the best BCS of ewes was half scores such as 2.5 or 3.5 shown in Figure 2.

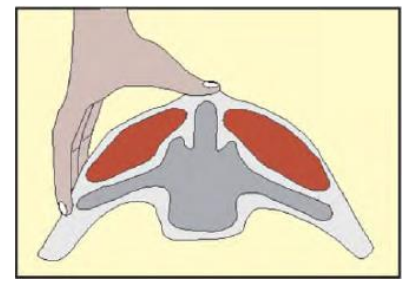

Figure 1 the vertical and horizontal bone protrusions are felt and used to assess an individual body condition score [30]

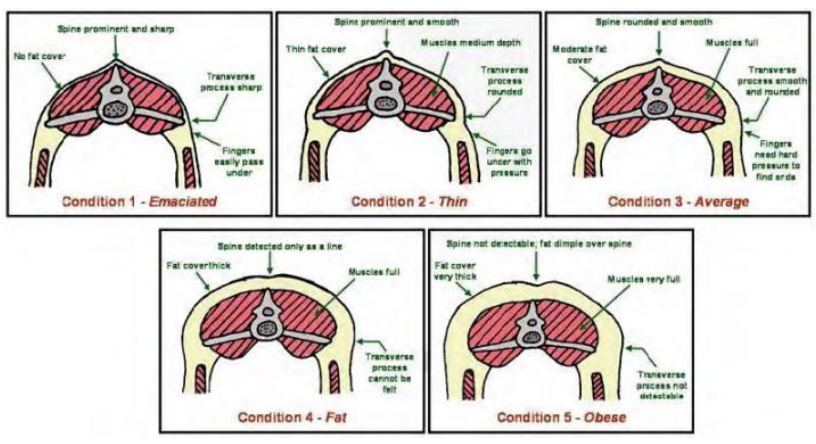

Figure 2 the system widely used in the united states on sheep or goat based on a scale of 1 to 5 ; (1) emaciated; (2) Thin; (3) average; (4) fat; and (5) obese [30]

\section{Measurement of Udder and Teat}

The procedure used for measuring the udder traits is stated in Figure 3 and was described by [31]. External udder measurements of Dorper sheep were included; udder length (UL), udder width (UW), rear udder depth (RUD), cistern depth (CD) and teat length (TL). The measurement was done by using measuring tape. The 32 of udder and teat of which the right and left udder side are measured from 16 ewes. 


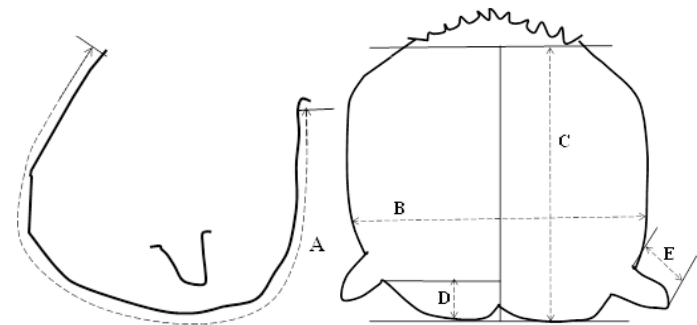

Figure 3 Measurement of udder and teat traits of sheep; (A) udder length (UL); (B) udder width (UW); (C) rear udder depth (RUD); (D) cistern depth (CD); (E) teat length (TL) [31]

\section{California Mastitis Test (CMT)}

The California mastitis test (CMT) was related to the number of somatic cells to the intensity of the reaction in milk and CMT was carried out for each individual milk samples collected from each quarter of udder either right and left side for the determination of somatic cell range according to the United States of National Mastitis Council guidelines [32]. About $2 \mathrm{~mL}$ of milk sample from each part of udder's sheep was collected. The 32 of milk samples of which the right and left udder side are counted as different samples of milk from 16 ewes and CMT reagent were mixed together in equal ratio volume by gently circular rotation and then the result were determined according to the formation of a viscous gel that were interpreted in brief where the scores represent four categories; 0 (no reaction or negative, - ), 1 (weak positive, +), 2 (distinct positive, ++ ), and 3 (strong positive, +++$)^{32}$.

\section{Statistical Analyses}

Coefficients and normal probability plot was performed to examine the data structure. Multiple Linear Regression test was performed to compare the live weight, body score condition (BCS) and traits of udder in relating to mastitis result. Besides, traits of the left and right teats were also compared to the mastitis result. The Pearson correlation for the relationships of the udder traits, live weight, body condition score and CMT were calculated. Probability values less than 0.05 were taken to be significant $(P<0.05)$. All calculations and analyses were performed using Microsoft ${ }^{\circledR}$ Excel 2007.

\section{Experimental Design}

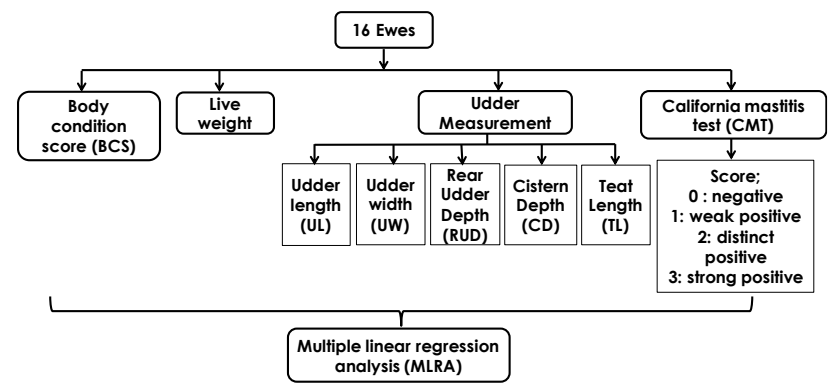

\subsection{RESULTS AND DISCUSSION}

The specific number of observations on the ewes' milk samples were depending on the California Mastitis Test (CMT) scores and lactation stage are shown in Table 1 and Table 2, respectively. Statistical analysis was performed by regular oneway analysis of variance (ANOVA) whereas Bonferroni post-test was used to check if there were significant differences between the groups. As shown in Table 1, the highest average of udder length $(301.0 \pm 10.1 \mathrm{~mm})$, udder width $(237.3 \pm 23.7$ $\mathrm{mm})$, rear udder depth $(222.7 \pm 17.7 \mathrm{~mm})$ and cistern depth $(91.7 \pm 6.5 \mathrm{~mm})$ were indicated in CMT score as strong positive (score $=3$ ) when compared to each CMT scores, respectively. In contrary, the smallest average of udder length $(250.5 \pm 22.6 \mathrm{~mm})$, udder width $(198.8 \pm 18.15 \mathrm{~mm})$, rear udder depth $(176.3 \pm 20.8 \mathrm{~mm})$ and cistern depth $(75.0 \pm 6.1 \mathrm{~mm})$ were indicated in CMT score as weak positive (score $=1$ ), respectively. However, the teat length $(39.0 \pm 3.6 \mathrm{~mm})$ showed the highest average in CMT score at weak positive (score $=1$ ) and the smallest average $(34.6 \pm 2.3 \mathrm{~mm})$ in CMT score at distinct positive (score $=2$ ), respectively.

This study shows that the measurement values of external ewes' udder are increased when the strength detection of CMT scores increased and vice versa; for example, when the udder traits values increased, the mastitis score detection become strong, with the exception of teat length measurement, this study indicates that the teat length is not affected by the strength of CMT scores. Besides, the current study shows that the higher value of cistern depth was associated to the strong positive of CMT score proposed that may be a bigger cistern may trigger a greater volume of residual milk in the teat that cause the pathogens may easy to multiply or due to the teat sphincter less of their patent that would increase the risk of bacterial entry into the teat canal [33]. However, the differences of external udder measurements in ewes when compared with the means of the groups of CMT scores show no significant differences $(P>0.05)$. This indicates that the measurement of CMT scores present in the milk samples did not affect the udder traits measurement. This result might be due to the diagnosis of sub-clinical mastitis in ewes apparently do not based on the inflammation or morphological alteration of mammary gland such as critical mastitis indicators. However, the quality of healthy milk production may potentially be affected indirectly. 
Table 1 The effect of subclinical mastitis based on California mastitis test (CMT) score on udder measurements (UL: udder length; UW: udder width; RUD: rear udder depth; CD: cistern depth; TL: teat length) of Dorper ewes (Mean \pm se)

\begin{tabular}{|c|c|c|c|c|c|c|}
\hline \multirow{2}{*}{$\begin{array}{l}\text { Source of } \\
\text { variation }\end{array}$} & \multirow[t]{2}{*}{$n$} & \multicolumn{5}{|c|}{ Udder measurement (mm) } \\
\hline & & UL & UW & RUD & $C D$ & $\mathrm{TL}$ \\
\hline $\begin{array}{c}0 \\
\text { (Negative) }\end{array}$ & $18^{1}$ & $\begin{array}{r}282.6 \\
\pm 10.8\end{array}$ & $\begin{array}{r}234.6 \\
\pm 11.3\end{array}$ & $\begin{array}{r}196.2 \\
\pm 11.9\end{array}$ & $\begin{array}{r}80.8 \\
\pm 5.2\end{array}$ & $\begin{array}{r}36.6 \\
\pm 1.4\end{array}$ \\
\hline $\begin{array}{l}1 \text { (weak } \\
\text { positive) }\end{array}$ & 4 & $\begin{array}{l}250.5 \\
\pm 22.6\end{array}$ & $\begin{array}{r}198.8 \\
\pm 18.2\end{array}$ & $\begin{array}{r}176.3 \\
\pm 20.8\end{array}$ & $\begin{array}{r}75.0 \\
\pm 6.1\end{array}$ & $\begin{array}{r}39.0 \\
\pm 3.6\end{array}$ \\
\hline $\begin{array}{l}2 \text { (distinct } \\
\text { positive) }\end{array}$ & 7 & $\begin{array}{l}303.1 \\
\pm 21.4\end{array}$ & $\begin{array}{r}233.6 \\
\pm 13.7\end{array}$ & $\begin{array}{c}202.4 \\
\pm 19.4\end{array}$ & $\begin{array}{c}86.4 \\
\pm \\
10.9\end{array}$ & $\begin{array}{r}34.6 \\
\pm 2.3\end{array}$ \\
\hline $\begin{array}{l}3 \text { (strong } \\
\text { positive) }\end{array}$ & 3 & $\begin{array}{l}301.0 \\
\pm 10.1\end{array}$ & $\begin{array}{r}237.3 \\
\pm 23.7\end{array}$ & $\begin{array}{r}222.7 \\
\pm 17.7\end{array}$ & $\begin{array}{r}91.7 \\
\pm 6.5\end{array}$ & $\begin{array}{r}36.8 \\
\pm 1.4\end{array}$ \\
\hline
\end{tabular}

Moreover, the variation of the external udder measurement of ewes of the samples milk depending on the days of lactation are observed and also obtained in Table 2. According to the results shown in Table 2, the highest average of udder length $(290.0 \pm 3.3 \mathrm{~mm})$, rear udder depth $(211.8 \pm 7.3$ $\mathrm{mm})$, and teat length $(41.8 \pm 1.8 \mathrm{~mm})$ were indicated in Group 3 (31 - 45 days of lactation) and udder width $(251.0 \pm 16.4 \mathrm{~mm})$ was shown in Group 2 (1630 days of lactation) when compared to each stage, respectively. In contrary, the smallest average of rear udder depth $(187.1 \pm 11.2 \mathrm{~mm})$ and teat length $(35.0$ $\pm 1.3 \mathrm{~mm}$ ) were indicated in early days of lactation of Group 1 (0-15 days of lactation), with exception of cistern depth $(76.0 \pm 3.7 \mathrm{~mm})$ and udder length $(279.4$ $\pm 9.6 \mathrm{~mm})$ were indicated in the Group $2(16-30$ days of lactation), where udder width (220.7 \pm 10.4 $\mathrm{mm}$ ) indicated in Group 3 (31 - 45 days of lactation), respectively. The highest or medium average results show that after prolonged days of lactation in Group 3 and 2, the external udder measurements of ewes were increased compared to the earlier period of lactation.

Table 2 The effect of subclinical mastitis based on California mastitis test (CMT) score on udder measurements (UL: udder length; UW: udder width; RUD: rear udder depth; CD: cistern depth; TL: teat length) at different days of lactation in Dorper ewes (Meantse)

\begin{tabular}{ccccccc}
\hline $\begin{array}{c}\text { Days of } \\
\text { lactation }\end{array}$ & $\mathbf{n}$ & \multicolumn{5}{c}{ Udder measurement (mm) } \\
& & UL & UW & RUD & CD & TL \\
\hline $\begin{array}{c}\text { Group 1 } \\
\text { (0-15 }\end{array}$ & 16 & 280.0 & 221.7 & 187.1 & 83.3 & 35.0 \\
days) & & \pm 15.8 & \pm 9.3 & \pm 11.2 & \pm 6.3 & \pm 1.3 \\
$\begin{array}{l}\text { Group 2 } \\
\text { (16-30 }\end{array}$ & 10 & 279.4 & 251.0 & 199.9 & 76.0 & 35.6 \\
$\begin{array}{c}\text { days) } \\
\text { Group 3 }\end{array}$ & 6 & 290.0 & 220.7 & 211.8 & 90.7 & 41.8 \\
$\begin{array}{c}\text { (31-45 } \\
\text { days) }\end{array}$ & & \pm 3.3 & \pm 10.4 & \pm 7.3 & \pm 4.8 & \pm 1.8 \\
\hline
\end{tabular}

UL: udder length; UW: udder width; RUD: rear udder depth; CD: cistern depth; TL: teat length.
This study suggests that the milking frequency will stimulate the milk secretion by ewes as that is the main regulation factor for obtain milk quantity and quality. By the duration prolong, the retention of milk in the mammary gland of ewes might be decreased by time as well as the lambs may suckling the milk easier during lactation period compared to the earlier stage of lactation [34, 35]. Moreover, the smallest average results of udder traits also shows that the parameters of external udder measurements of rear udder depth and teat length (exception of cistern depth) were decreased in measurements size in the earlier stage of lactational period compared to the last stage of lactation due to their mammary tissue is still in developing stage.

Udder morphology measurement increased throughout the lactation stage but the difference statistically were not positively significant ( $p>0.05)$. These results were disagreeing with previous reports by [36] which is udder traits was declined during the lactation. In this study, prolong days of lactation shows an increment of cistern depth (UD) of ewes when compared to earlier days of lactation. This probably due to the increased size of cisternal that was correlated to the total milk yield produce greater during milking period and gland cistern become larger to support milk storage [36].

Basic statistical characteristics of the selected parameters variation on characterizing external udder measurements of ewes for Dorper breed are shown in Table 3, including udder length (UL), udder width (UW), rear udder depth (RUD), cistern depth (CD) and teat length (TL). According to this study, there was different variability shown on values among the udder traits. Therefore, the coefficient of variation (CV) had shown in Table 3 represents the ratio of standard deviation (SD) to the mean for each parameter of ewe's udder traits during sample milk collection. Moreover, CV values are the basic statistical characteristic which may useful for comparing the degree of variation across different udder parameters.

The lowest average value for the external udder sizes of ewes was indicated in the teat length (TL) at $(36.5 \pm 1.0 \mathrm{~mm})$. Whilst, the highest average value was indicated in the udder length $(281.7 \pm 8.5 \mathrm{~mm})$ and the average value of udder length was characterized in large margin range where the minimum value of this parameter was measured at $180 \mathrm{~mm}$ and a maximum value at $400 \mathrm{~mm}$. Coefficient of variation for external udder parameters were medium high where it shows that all traits of the monitored ewes were not ignored $(>0 \mathrm{~mm})$ where there is absent of 'zero' value of minimum for each traits. 
Table 3 The basic statistical characteristics of the selected parameters variations on characterizing the external udder measurements of Dorper ewes

\begin{tabular}{ccccccc}
\hline Traits & $\mathbf{n}$ & Mean & SD & CV & Min & Maxi \\
\hline $\begin{array}{c}\text { Udder } \\
\text { length, } \\
\text { mm }\end{array}$ & 32 & $\begin{array}{c}281.7 \\
\pm 8.5\end{array}$ & 48.0 & 17.0 & 180 & 400 \\
$\begin{array}{c}\text { Udder } \\
\text { width, } \\
\text { mm }\end{array}$ & 32 & $\begin{array}{c}230.1 \pm \\
7.9\end{array}$ & 45.1 & 19.6 & 160 & 307 \\
$\begin{array}{c}\text { Rear } \\
\text { vdder } \\
\text { depth, } \\
\text { mm }\end{array}$ & 32 & $\begin{array}{c}197.6 \pm \\
8.7\end{array}$ & 49.2 & 24.9 & 125 & 265 \\
$\begin{array}{c}\text { Cistern } \\
\text { depth, } \\
\text { mm }\end{array}$ & 32 & $82.3 \pm$ & 22.4 & 27.2 & 55 & 130 \\
$\begin{array}{c}\text { Teat } \\
\text { length, } \\
\text { mm }\end{array}$ & 32 & $36.5 \pm$ & 5.9 & 16.2 & 25 & 49 \\
\hline
\end{tabular}

SD: standard deviation; CV: coefficient of variability; Min: minimum; Max: maximum.

Results of multiple linear regressions (MLR) are estimated. The correlation effect of the CMT scores on the selected external udder traits and was summarized in Table 4. Linear regression coefficients for all external udder measurements as well as live weight, body condition scores (BCS) and CMT scores were estimated and shown in Table 4. All external udder traits and CMT scores were performed with coefficient in regression in order to compare trends. Results show that live weight (0.0080), udder length (0.0020), rear udder depth (0.0030) and cistern depth (0.0070) exhibited positive trend, although it was small, respectively.

Meanwhile, according to adjusted $\mathrm{R}^{2}$ result shows that the correlations between BCS $(-0.3125)$, udder width $(-0.0002)$ and teat length $(-0.0130)$ showed weak correlations with CMT scores, respectively. This means that when the scores of CMT increases, the BCS, udder width and teat length decrease as well as vice versa. The MLR model for all udder traits, live weight and BCS in this study shows clearly that there is no significant different and the parameters for all udder traits measured did not influenced by CMT score's strength due to the $p$-values are more than 0.05 ( $P>0.05$ ). The present study means that good udder conformation or live weight or BCS are not associated with the increase risk of mastitis in Dorper sheep. In contrast, the previous study by [37] indicated that the risk of mastitis infection is associated with udder conformation where the pendulous udder with the extreme teat position and greater cross-sectional area of the teats in dairy ewes resulted increase the risk of mastitis infection in ewes compared to the normal udder conformation [28] also stated that the pendulous udder will make the lamb difficult to suckle effectively and did not feed sufficiently which may trigger the lamb attempt to repeated suckling that could lead to teat lesions or intramammary infection.

Table 4 The results of multiple linear regression analysis for all parameters (i.e. live weight $(\mathrm{kg})$, body condition score $(1$ to $5)$, udder length $(\mathrm{mm})$, udder width $(\mathrm{mm})$, rear udder $(\mathrm{mm})$, cistern $(\mathrm{mm})$ and teat length $(\mathrm{mm})$ involved in assessment on subclinical mastitis effects of Dorper ewes

\begin{tabular}{ccccc}
\hline Traits & coefficient & p-value & $\mathbf{R}^{2}$ & $\begin{array}{c}\text { Adjusted } \\
\mathbf{R}^{2}\end{array}$ \\
\hline $\begin{array}{c}\text { Live weight, } \\
\text { Kg }\end{array}$ & 0.0083 & 0.8963 & $\begin{array}{c}0.000 \\
6\end{array}$ & -0.0327 \\
$\begin{array}{c}\text { Body } \\
\text { condition } \\
\text { score }\end{array}$ & -0.3125 & 0.4220 & 0.021 & -0.0110 \\
Udder & 0.0020 & 0.6186 & 0.008 & -0.0250 \\
$\begin{array}{c}\text { length, mm } \\
\text { Udder }\end{array}$ & -0.0002 & 0.9650 & 0.000 & -0.0330 \\
width, mm & & & 1 & \\
$\begin{array}{c}\text { Rear udder } \\
\text { depth, mm }\end{array}$ & 0.0027 & 0.4970 & 0.016 & -0.0170 \\
$\begin{array}{c}\text { Cistern } \\
\text { depth, mm }\end{array}$ & 0.0070 & 0.4200 & 0.022 & -0.0100 \\
$\begin{array}{c}\text { Teat length, } \\
\text { mm }\end{array}$ & -0.0130 & 0.6920 & 0.005 & -0.0300 \\
\hline
\end{tabular}

Moreover, the adjusted $\mathrm{R}^{2}$ is important value that used in the model for checking their quality of prediction [38]. The adjusted $R^{2}$ values in this study showed negative values for all external udder traits, live weight and BCS. The small values of adjusted $R^{2}$ could happen if $R^{2}$ is zero and after the adjustment the values can deep below zero. The low adjusted $\mathrm{R}^{2}$ indicates that the regression model is a poor fit for data point for each trait. These results explained that this may be caused by the presence of parameters among the external udder traits, live weight and BCS that not directly influence mastitis score in the regression model.

This means that weak contribution from all traits in relationship with mastitis infection in sample's milk. The adjusted $R^{2}$ results also along with $p$-values were greater than 0.05 which is no significant statistically between traits and mastitis scores. In contrast, previous study showed that adjusted $\mathrm{R}^{2}$ values of lactation curves of milk yield traits of Holstein cow were similar indicated that present of positive correlation between the traits [38].

In addition, the graph for all parameters against CMT score was plotted in Figure 4 and shows small values of $R^{2}$ including live weight $\left(R^{2}=0.0006\right), B C S\left(R^{2}\right.$ $=0.0216)$, udder length $\left(R^{2}=0.0084\right)$, udder width $\left(R^{2}\right.$ $=0.0001)$, rear udder depth $\left(R^{2}=0.0160\right)$, cistern depth $\left(R^{2}=0.0220\right)$ and teat length $\left(R^{2}=0.0053\right)$, 
respectively. The small values of $\mathrm{R}^{2}$ means that the live weight, BCS and external udder traits were weak data points to fit the regression model which were not suitable parameter to predict the response of mastitis in sheep. The result in an agreement with the previous study by also showed that the lowest estimate value $\left(R^{2}=9 \%\right)$ of the model among the type traits including animal's genotype, the flock conditions, their age, season and year of birth, calving month and the number of daily milking which is weak contribution in directly influence 305 milking days (MY1) of goats [39].

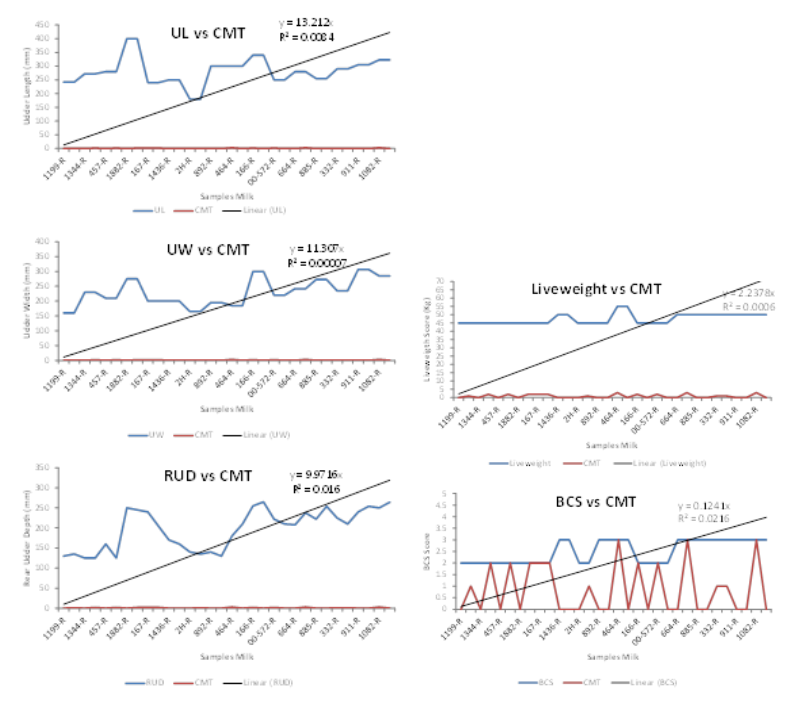

Figure 4 The plot graph of live weight, body condition score (BCS) and all the external udder traits; udder length, udder width, rear udder, cistern and teat length against California mastitis test (CMT) in Dorper ewes' milk samples

\subsection{CONCLUSION}

In comparing the variation of CMT scores and days of lactation, there were small differences and not statistically significant which indicated that the live weight, BCS and all external udder traits were not affected by subclinical mastitis in Dorper sheep. Still the subclinical mastitis infection scores detected in milk's samples cannot be ignored as it could potentially affect milk quantity and quality as well as sheep growth rates. Hence, the inclusion result of the mastitis infection scores obtained from milk's samples in this study may help reduce the incidence of mastitis in the Dorper sheep. The major advancement and contribution to the body of knowledge was the evaluation of subclinical mastitis with growth (i.e. live weight with body condition score (BSC)) and udder size of Dorper sheep.

\section{Acknowledgement}

This study was fully supported by the project of Fundamental Research Grant Scheme (FRGS)
(FRGS/1/2018/STG05/UNISZA/02/1) "Recombinant Alginate Lyase Protein as Potential Inhibitor of Biofilm formation in Carbapenems Resistance Pseudomonas aeruginosa", Special Research Grant Scheme (SRGS) (UniSZA/2017/SRGS/04) "Investigation of Multidrug Resistant Mechanism in Pseudomonas aeruginosa isolated from small ruminant with mastitis" and Agropolitan Farm Besut-Setiu. The authors fully acknowledged the Ministry of Higher Education (MOHE) and Universiti Sultan Zainal Abidin for the approved fund which makes this important research viable and effective.

\section{References}

[1] Novac, C. S., Andrei, S. 2020. The Impact of Mastitis on the Biochemical Parameters, Oxidative and Nitrosative Stress Markers in Goat' S Milk: A Review. Pathogens. 9: 882.

[2] Olechnowicz, J. A. N., Jaśkowski, J. M. 2014. Mastitis in Small Ruminants. Medycyna. Weterynaryjna. 70(2): 67-72. Doi: 10.1016/j.smallrumres.2006.09.011.

[3] Brian K. 2015. Sheep Diseases Directory. Agric Hortic Dev Board. 1-33.

[4] K. M. Charon, K. M. 1993. Morphological Characteristics of Udders as Selection Criteria for Improvement of Mammary Gland Health and Productivity of Sheep. 2. The Relationship Between Udder Morphology and the Health and Productivity of Ewes. Journal of Animal and Feed Sciences. 2: 117-127. Doi: 10.22358/jafs/69873/1993.

[5] Mclaren, A., Kaseja, K., Yates, J., Mucha, S., Lambe, N. R. Conington, J. 2018. New Mastitis Phenotypes Suitable for Genomic Selection in Meat Sheep and Their Genetic Relationships with Udder Conformation and Lamb Live Weights. Anim Consort. 1-10. Doi:10.1017/S1751731118000393

[6] Bagri, D. K., Pandey, R. K., Bagri, G. K., Kumari, R., Bagdi, D. L. 2018. Effect of Subclinical Mastitis on Milk Composition in Lactating Cows. J Entomol Zool Stud. 6(5): 231-236.

[7] Bhutto, A. L., Murray, R. D., Woldehiwet, Z. 2012. California Mastitis Test Scores as Indicators of Subclinical IntraMammary Infections at the End of Lactation in Dairy Cows. Res Vet Sci. 92(1): 13-17. Doi:10.1016/j.rvsc.2010.10.006.

[8] Jimenez-granado, R., Sanchez-rodriguez, M., Arce, C. Rodriguez-Estevez, V. 2014. Factors Affecting Somatic Cell Count in Dairy Goats: A Review. Spanish J Agric Res. 12(1): 133-150.

[9] Persson, Y., Olofsson, I. 2011. Direct and Indirect Measurement of Somatic Cell Count as Indicator of Intramammary Infection in Dairy Goats. Acta Vet Scand. 53(1): 15. Doi:10.1186/1751-0147-53-15.

[10] Akdag, F., Teke, B., Ugurlu, M., Onyay, F. B., Kocak, O., Demir, H. 2018. Udder types and Associated Traits Affect Milk Composition and Subclinical Mastitis in Karayaka Sheep. Indian J Anim Sci. 88(10): 1186-1192.

[11] Machado, G. P. 2018. Mastitis in Small Ruminants. Anim Husbandry, Dairy Vet Sci. 2(4): 1-9. Doi:10.15761/AHDVS.1000144.

[12] Vasileiou, N. G. C., Chatzopoulos, D. C., Sarrou, S., et al. 2019. Role of Staphylococci in Mastitis in Sheep. J Dairy Resear. 86: 254-266.

[13] Contreras, A., Sierra, D., Sánchez, A., et al. 2007. Mastitis in Small Ruminants. Small Rumin Res. 68: 145-153. Doi:10.1016/j.smallrumres.2006.09.011.

[14] Hassan, H. J. 2013. Variations in Milk Composition of Some Farm Animal Resulted by Sub-clinical Mastitis in Al-Diwania Province. Basrah J Vet Res. 12(2): 17-24.

[15] Gelasakis, A. I., Mavrogianni, V. S., Petridis, I. G., Vasileiou, N. G. C. , Fthenakis, G. C. 2015. Mastitis in Sheep - The Last 10 Years and the Future of Research. Vet Microbiol. 181: 
136-146. Doi:10.1016/j.vetmic.2015.07.009.

[16] Mørk, T., Waage, S., Tollersrud, T., Kvitle, B., Sviland, S. 2007. Clinical Mastitis in Ewes; Bacteriology, Epidemiology and Clinical Features. Acta Vet Scand. 8: 1-8. Doi:10.1186/1751-0147-49-23.

[17] Fragkou, I. A., Boscos, C. M., Fthenakis, G. C. 2014 Diagnosis of Clinical or Subclinical Mastitis in Ewes. Small Rumin Res. 118(1-3): 86-92. Doi:10.1016/j.smallrumres.2013.12.015.

[18] Kandeel, S. S., Morin, D. E., Calloway, C. D., Constable, P. D. 2018. Association of California Mastitis Test Scores with Intramammary Infection Status in Lactating Dairy Cows Admitted to a Veterinary Teaching Hospital. J Vet Intern Med. 32: 497-505. Doi:10.1111/jvim.14876.

[19] Alekish, M. O., Ismail, Z. B., Hammouri, H. M., Daradka, M. H., Taha, S. A., Olymat, I. 2018. Bacteriological Cure Rate and Changes in Milk Composition in Mastitis Vaccinated Ewes Affected with Subclinical Mastitis. Vet World. 11: 125129. Doi:10.14202/vetworld.2018.125-129.

[20] Gelasakis, A. I., Angelidis, A. S., Giannakou, R., Filioussis, G. Kalamaki, M. S., Arsenos, G. 2016. Bacterial Subclinical Mastitis and Its Effect on Milk Yield in Low-Input Dairy Goat Herds. Am Dairy Sci Assoc. 99: 1-11. Doi:10.3168/jds.201510694.

[21] Persson, Y., Larsen, T., Nyman, A. -k. 2014. Variation in Udder Health Indicators at Different Stages of Lactation in Goats with No Udder Infection. Small Rumin Res. 116(1): 51-56. Doi:10.1016/j.smallrumres.2013.10.004.

[22] Ismail, Z. B., Alekish, M., Al-Sheyab, O. 2016. Relationships between Somatic Cell Count and Certain Udder and Teat Echo-Morphometric Measurements in Mastitis Caused by Staphylococcus Aureus in Awassi Sheep. Rev Med Vet. 167(1-2): 33-37.

[23] Casu, S., Sechi, S., Salaris, S. L., Carta, A. 2010. Phenotypic and Genetic Relationships between Udder Morphology and Udder Health in Dairy Ewes. Small Rumin Res. 88: 7783. Doi:10.1016/j.smallrumres.2009.12.013.

[24] Hussain, R., Javed, M. T., Khan, A., Mahmood, F., Kausar, R. 2012. Mastitis and Associated Histo-pathologica Consequences in the Context of Udder Morphology. Int J Agric Biol. 14(6): 947-952.

[25] Kamal, R. M., Bayoumi, M. A., Abd El Aal, S. F. A. 2014. Correlation between Some Direct and Indirect Tests for Screen Detection of Subclinical Mastitis. Int Food Res J. 21 (3): 1249-1254.

[26] Peixoto, R. de M., Araújo, R, de M. P., Peixoto, L. J. e S, et al. 2016. Indirect Dagnostic Tests for the Detection of Subclinical Mastitis in Dairy Goats Experimentally Infected with Staphylococcus Aureus. Ciência Rural. 46(7): 12171222. Doi:10.1590/0103-8478cr20150507.

[27] McDougall, S., Supré, K., De Vliegher, S., et al. 2010. Diagnosis and Treatment of Subclinical Mastitis in Early Lactation in Dairy Goats. J Dairy Sci. 93: 4710-4721.
Doi:10.3168/jds.2010-3324.

[28] Green, L., Grant, C., Whatford, L. 2016. Understanding Mastitis in Sheep. AHDB. 1-17.

[29] Kusminanto, R. Y., Alawiansyah, A., Pramono, A., Sutarno, Cahyadi, M. 2020. Body weight and Body Measurement Characteristics of Seven Goat Breeds in Indonesia. Earth Environ Sci. 478: 1-6. Doi:10.1088/1755-1315/478/1/012039

[30] Thompson, J., Meyer, H. 1994. Body Condition Scoring of Sheep. In Pract. 1-4. Doi:10.1136/inpract.6.3.91.

[31] Makovický, P., Nagy, M., Makovický, P. 2013. Comparison of External Udder Measurements of the Sheep Breeds Improved Valachian, Tsigai, Lacaune and Their Crosses. Chil J Agric Res. 73(4): 366-371. Doi:10.4067/S071858392013000400006.

[32] Abdalhamed, A. M, Zeedan, G. S. G., Zeina, H. A. A. A. 2018. Isolation and Identification of Bacteria Causing Mastitis in Small Ruminants and Their Susceptibility to Antibiotics, Honey, Essential Oils, and Plant Extracts. Vet World. 11 (3): 355-362. doi:10.14202/vetworld.2018.355-362.

[33] Huntley, S. J., Cooper, S., Bradley, A. J., Green, L. E. 2012. A Cohort Study of the Associations Between Udder Conformation, Milk Somatic Cell Count, and Lamb Weight in Suckler Ewes. J Dairy Sci. 95(9): 5001-5010. Doi:10.3168/jds.2012-5369.

[34] Marnet, P. G., Komara, M. 2008. Management Systems with Extended Milking Intervals in Ruminants : Regulation of Production and Quality of Milk. Am Soc Anim Sci. 86(1): 4756. Doi:10.2527/jas.2007-0285.

[35] Davis, S. R. 2017. Triennial Lactation Symposium/Bolfa: Mammary Growth during Pregnancy and Lactation and Its Relationship with Milk Yield. Am Soc Anim Sci. 95: 56755688. Doi:10.2527/jas2017.1733.

[36] Ayadi, M., Matar, A. M., Aljumaah, R. S., Alshaikh, M. A., Abouheif, M. A. 2014. Evolution of Udder Morphology, Alveolar and Cisternal Milk Compartment During Lactation and Their Relationship with Milk Yield in Najdi Sheep. Spanish J Agric Res. 12(4): 1061-1070.

[37] Cooper, S., Huntley, S. J., Crump, R., Lovatt, F., Green, L. E. 2016. A Cross-sectional Study of 329 Farms in England to Identify Risk Factors for Ovine Clinical Mastitis. Prev Vet Med. 125: 89-98. Doi:10.1016/j.prevetmed.2016.01.012.

[38] Hossein-zadeh, N. G. 2017. Application of Growth Models to Describe the Lactation Curves for Test-day Milk Production in Holstein Cows. J Appl Anim Res. 45(1): 145151. Doi:10.1080/09712119.2015.1124336.

[39] Valencia-posadas, M., Barboza-corona, J. E., Ángelsahagún, C. A., Gutiérrez-chávez, A. J., Martínez-jaime, O. A. Montaldo, H. H. 2017. Phenotypic Correlations between Milk Production and Conformation Traits in Goats. Acta Univ. 27(3): 3-8. Doi:10.15174/au.2017.1093. 